\title{
Pneumonia in mice produced by Neisseria gonorrhoeae
}

\author{
A. P. JOHNSON, D. TAYLOR-ROBINSON, AND G. SLAVIN \\ From the MRC Clinical Research Centre, and Northwick Park Hospital, Watford Road, Harrow, Middlesex
}

SUMMARY Gonococci of colony type 1 were introduced by intranasal inoculation into the lungs of mice in an attempt to produce infection. The organisms were eliminated from the three strains of mice used within 24 hours of challenge. Cyclophosphamide treatment of mice failed to render them susceptible although the organisms disappeared more slowly. The lungs of immunologically normal animals that had received either viable or heat-killed gonococci were acutely inflamed with infiltration of bronchioles and alveoli by polymorphonuclear and mononuclear leucocytes. Most of the changes had resolved after about four days. In cyclophosphamide-treated mice pulmonary infiltration by polymorphonuclear leucocytes was not evident, suggesting that these cells were not primarily responsible for the clearance of the gonococci. Despite the failure to produce a sustained infection, this model may be valuable for studying the local inflammatory effect of gonococcal endotoxin.

\section{Introduction}

One of the major difficulties confronting investigators in the study of gonococcal infections is the lack of a convenient animal model. Lucas et al. (1971) reported that gonococcal urethritis had been produced in male chimpanzees using urethral exudates obtained from human males. Further work with this system (Brown et al., 1972) confirmed the observations of Kellogg et al. (1963) that genital infections may be established experimentally if virulent colony types (designated T1 and T2) are used. However, since chimpanzees are not readily available, these studies have been limited. Recently, Arko (1972) reported observations on the fate of gonococci inoculated into artificial chambers implanted subcutaneously in several species of small laboratory animals, and similar studies have been reported subsequently by other workers (Flynn and Waitkins, 1973; Scales and Kraus, 1974; Veale et al., 1975; Turner and Novotny, 1976). Although the immunological and pathological events occurring in this system have been investigated (Arko, 1974; Chandler et al., 1976) their relevance to human infection is not clear, as gonococcal infections in man normally involve infection of a mucosal surface. It is known

Address for reprints: Dr D. Taylor-Robinson, Clinical Research Centre, Watford Road, Harrow, Middlesex HA1 3UJ

Received for publication 23 August 1976 that special immunological mechanisms, in particular the production of local secretory antibody (IgA), may be important in infections of mucosal surfaces, and it is unlikely that such host defence mechanisms would be operative in the chamber model. There is, therefore, still a need for a convenient animal model in which infection of a mucosal surface is a central feature. This report describes attempts to produce such a model, by inoculation of gonococci into the lower respiratory tract of mice.

\section{Materials and methods}

\section{MICE}

Young adult, female, CBA, Balb/C, or A strain mice weighing $15-20 \mathrm{~g}$ were used, usually in groups of at least four. All mice were specific pathogen-free.

IMMUNOSUPPRESSION

Mice were injected intraperitoneally with a single dose of cyclophosphamide ( $300 \mathrm{mg} / \mathrm{kg}$ body weight) either three days before, or at the time of inoculation with Neisseria gonorrhoeae.

IRON TREATMENT

Ammonium ferric citrate, $625 \mathrm{mg}$ (20.5-22.5\% iron; Hopkin and Williams), was dissolved in $100 \mathrm{ml}$ isotonic saline and the solution autoclaved at a temperature of $121^{\circ} \mathrm{C}$ for 15 minutes. Mice were inoculated intraperitoneally so that they received 
$10 \mathrm{mg}$ iron/kg body weight 18 hours and 1 hour before challenge with gonococci.

BACTERIA AND PREPARATION OF INOCULA The strains of $N$. gonorrhoeae used were F62, 2686, 192A, 203H, and Sal.

The identity of organisms was confirmed by typical colony morphology, Gram-negative stain, positive oxidase reaction and the ability to ferment glucose, but not maltose or sucrose. Colony types were identified according to the criteria of Kellogg $e t$ al. (1963).

Gonococci were cultured on medium which consisted of GC agar base (Difco) supplemented with $2 \%$ volume by volume Isovitalex (BBL). After multiplication for 20-24 hours at a temperature of $37^{\circ} \mathrm{C}$ in an atmosphere of $2 \% \mathrm{CO}_{2}$ in air, organisms of the desired colony type were scraped from the agar surface with a platinum loop, and suspended in about $4 \mathrm{ml}$ of Eagle's minimal essential medium (MEM) containing $0.05 \mathrm{~mol} / 1$ HEPES buffer (pH 7-3). The suspension was agitated for 30-60 seconds on a Rotamixer Deluxe (Hook and Tucker Ltd) at maximal amplitude to disperse bacterial clumps.

In one experiment, gonococci were killed by heating a suspension to a temperature of $56^{\circ} \mathrm{C}$ for 1 hour.

\section{INOCULATION PROCEDURE}

Mice were anaesthetised by intraperitoneal injection of pentobarbitone sodium $(0.06 \mathrm{mg} / \mathrm{g}$ body weight $)$ and then inoculated intranasally with $0.05 \mathrm{ml}$ of the gonococcal suspension. Animals used as controls were inoculated intranasally with an equivalent volume of medium. After all the animals had been inoculated, the titre of the inoculum was determined by making serial 10 -fold dilutions, and plating $0.05 \mathrm{ml}$ of each dilution on the solid medium described above.

PROCEDURE FOR RE-ISOLATION OF ORGANISMS Mice were killed by injecting intraperitoneally $0.1 \mathrm{ml}$ of undiluted pentobarbitone sodium solution followed by bleeding from the axillary vessels. The trachea was exposed and the thoracic cage removed. The lungs were washed in situ with 1-2 ml of Eagle's MEM, this being introduced and withdrawn three times through a canula tied securely into the trachea (Taylor-Robinson et al., 1972). Then $0 \cdot 1 \mathrm{ml}$ of the lung washing was spread on to GC agar medium containing Isovitalex and incubated as described previously to detect bacterial colonies.

HISTOLOGICAL PROCEDURES

After collection of the lung washings for bacterial isolation, the lungs were redistended with $1-2 \mathrm{ml}$ of buffered formol saline. The lungs were then removed and immersed in the same fixative for at least 24 hours. After fixation, blocks were embedded in paraffin wax, sectioned and stained with haematoxylin and eosin. Histological sections were coded before examination so that they were assessed without knowledge of the treatment which the animals had received. In some experiments, the technique of Sowter and McGee (1976) was used to detect gonococci. The lungs were fixed with formol sublimate and the sections stained with Grammethyl green-pyronin-light green (Gram-MGPLG).

\section{Results}

ATTEMPTS TO RE-ISOLATE GONOCOCCI FROM THE LUNGS

In initial studies, gonococci (strain Sal) of colony type 4 were inoculated into CBA mice. Attempts to re-isolate organisms from their lungs one, two, three, and four days later were uniformly negative. Consequently, in subsequent experiments, gonococci of colony type 1 were used, as this colonial morphology is known to be associated with virulence (Kellogg et al., 1963). Furthermore, in addition to CBA mice, Balb/C and A strain mice were inoculated. The results of attempts to infect the respiratory tract of these mice with four strains of $N$. gonorrhoeae are shown in Table 1. Despite inoculation of at least $10^{7}$ colony-forming units, gonococci were rarely isolated 24 hours later and appeared to have been completely eliminated from the lungs by 48 hours. Similar results were obtained with mice that had been pre-treated with iron. However, in immunosuppressed animals, the rate of clearance of gonococci from the lungs was slower, organisms being isolated from a larger number of mice after 24 hours (Table 2). Nevertheless, even in these animals, gonococci were rarely recovered 48 hours after inoculation (Table 2).

Table 1 Recovery of $\mathrm{N}$. gonorrhoeae from lungs of mice inoculated intranasally with type 1 organisms

\begin{tabular}{|c|c|c|c|c|c|}
\hline \multirow{2}{*}{\multicolumn{2}{|c|}{$\begin{array}{l}\text { Strain of } \\
\text { N. gonorrhoeae }\end{array}$}} & \multirow[t]{2}{*}{$\begin{array}{l}\text { Titre of } \\
\text { inoculum } \\
\text { (colony-forming } \\
\text { units } / 0.05 \mathrm{ml} \text { ) }\end{array}$} & \multirow[t]{2}{*}{$\begin{array}{l}\text { Strain of } \\
\text { mouse }\end{array}$} & \multicolumn{2}{|c|}{$\begin{array}{l}\text { No. of } \\
\text { re-isolations/ } \\
\text { No. of mice } \\
\text { inoculated }\end{array}$} \\
\hline & & & & Day 1 & Day 2 \\
\hline $\begin{array}{l}\text { F62 } \\
2686 \\
192 A \\
203 H \\
2686 \\
2686\end{array}$ & $\begin{array}{l}\text { T1 } \\
\text { T1 } \\
\text { T1 } \\
\text { T1 } \\
\text { T1 } \\
\text { T1 }\end{array}$ & $\begin{array}{l}1 \times 10^{7} \\
7 \times 10^{7} \\
4 \times 10^{8} \\
2 \times 10^{7} \\
1 \times 10^{7} \\
2 \times 10^{7}\end{array}$ & $\begin{array}{l}\text { CBA } \\
\text { CBA } \\
\text { CBA } \\
\text { CBA } \\
\text { Balb/C } \\
\text { A strain }\end{array}$ & $\begin{array}{l}2 / 8 \\
0 / 6 \\
2 / 6 \\
0 / 9 \\
0 / 5 \\
0 / 4\end{array}$ & $\begin{array}{l}0 / 8 \\
0 / 6 \\
0 / 5 \\
0 / 7 \\
0 / 5 \\
0 / 4\end{array}$ \\
\hline
\end{tabular}




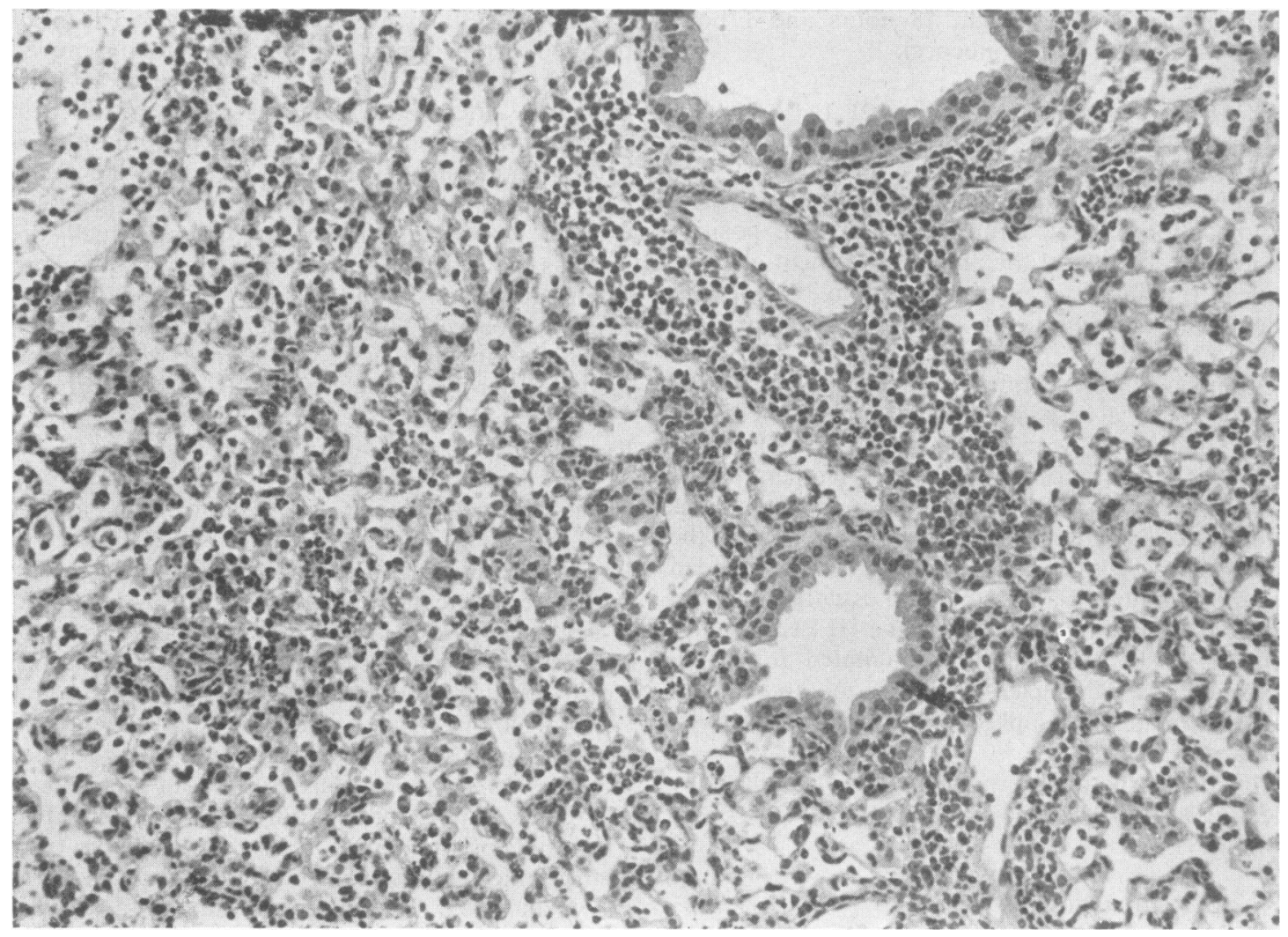

Fig. 1 Lung of CBA mouse 48 hours after intranasal inoculation of gonococci. There is a well-marked polymorphonuclear leucocyte and mononuclear cell infiltration of alveoli with pronounced perivascular and peribronchiolar cuffing. $H$ and $E, \times 225$.

HistopatholOGICAL CHANGES IN THE LUNGS Introduction of gonococci into the lungs of the three strains of mice produced a transient but severe pneumonia. Earliest lesions consisted of inflammation around respiratory bronchioles and vessels with polymorphonuclear leucocyte and mononuclear cell infiltration of alveoli. The changes were at their severest about 48 hours after inoculation when perivascular cuffing with inflammatory cells was prominent (Fig. 1), and occasionally there was an active vasculitis of small vessels. In severely affected lungs, focal degeneration of bronchiolar epithelium was sometimes seen. In addition, there was pleural inflammatory involvement which was inconstant but focally well marked (Fig. 2). The acute inflammation had largely resolved by day 4 , there being only mononuclear cells present in alveoli.

No pneumonia was observed in mice which had been given cyclophosphamide three days before intranasal challenge with gonococci. In such mice
Table 2 Recovery of $\mathrm{N}$. gonorrhoeae from lungs of normal and cyclophosphamide-treated CBA mice inoculated intranasally with type 1 organisms

\begin{tabular}{|c|c|c|c|c|c|}
\hline \multicolumn{2}{|c|}{$\begin{array}{l}\text { Strain of } \\
\text { N. gonorrhoeae }\end{array}$} & \multirow{2}{*}{$\begin{array}{l}\text { Titre of } \\
\text { inoculum } \\
(\text { colony-forming } \\
\text { units } / 0.05 \mathrm{ml})\end{array}$} & \multirow{2}{*}{$\begin{array}{l}\text { Treatment of } \\
\text { mouse }\end{array}$} & \multicolumn{2}{|c|}{$\begin{array}{l}\text { No. of } \\
\text { re-isolations/ } \\
\text { No. of mice } \\
\text { inoculated } \\
\text { Day } 1 \quad \text { Day } 2\end{array}$} \\
\hline $\begin{array}{l}192 A \\
192 A\end{array}$ & $\begin{array}{l}\text { T1 } \\
\text { T1 }\end{array}$ & & & $0 / 6$ & $0 / 6$ \\
\hline $\begin{array}{l}2686 \\
2686\end{array}$ & $\begin{array}{l}\text { T1 } \\
\text { T1 }\end{array}$ & $\begin{array}{l}5 \cdot 2 \times 10^{6} \\
5 \cdot 2 \times 10^{6}\end{array}$ & $\begin{array}{l}\text { Untreated } \\
\text { CY } 3 \text { days } \\
\text { before inocu- } \\
\text { lation with } N \text {. } \\
\text { gonorrhoeae }\end{array}$ & $0 / 4$ & $0 / 4$ \\
\hline $\begin{array}{l}2686 \\
2686\end{array}$ & $\begin{array}{l}\text { T1 } \\
\text { T1 }\end{array}$ & $\begin{array}{l}2 \times 10^{7} \\
2 \times 10^{7}\end{array}$ & $\begin{array}{l}\text { Untreated } \\
\text { CY at same } \\
\text { time as inocu- } \\
\text { lation with } N \text {. } \\
\text { gonorrhoeae }\end{array}$ & $0 / 6$ & $0 / 6$ \\
\hline
\end{tabular}

*CY = cyclophosphamide $(300 \mathrm{mg} / \mathrm{Kg}$ body weight $)$. 
the only pathological changes observed were slight interstitial thickening of alveolar walls, and occasionally an increase in the number of mononuclear cells in the alveoli. In mice which were given cyclophosphamide and gonococci at the same time, there was a diffuse polymorphonuclear leucocyte infiltration of the lungs after two days, which was less severe than that observed in immunologically normal mice challenged with the same dose of gonococci. Immunologically normal and cyclophosphamidetreated mice inoculated with medium only did not develop lung lesions. In the experiment in which two groups of mice were inoculated with equivalent numbers of viable and heat-killed gonococci, respectively, similar pathological changes were observed in both groups of animals.

Gonococci were not demonstrable histologically in any of the lungs stained with either haematoxylin and eosin or Gram-MGPLG.

\section{Discussion}

There have been a number of studies of gonococcal infections in small laboratory animals in which observations have been made on the fate of gonococci introduced into subcutaneous chambers (Arko, 1972, 1974; Flynn and Waitkins, 1973). The pathological changes consist of an intense polymorphonuclear leucocyte infiltration, with tissue necrosis (Veale et al., 1975; Chandler et al., 1976). However, such a model is not entirely analogous to nondisseminated gonococcal infection in man, as there is no interaction of gonococci with a mucosal surface. The pathological changes at a mucosal surface may require initial attachment of the organisms mediated by pili and then toxin liberation or some other, as yet, unidentified event. On the other hand, attachment of organisms to cells may not be an important factor in the development of pathological changes in chambers where the organ-

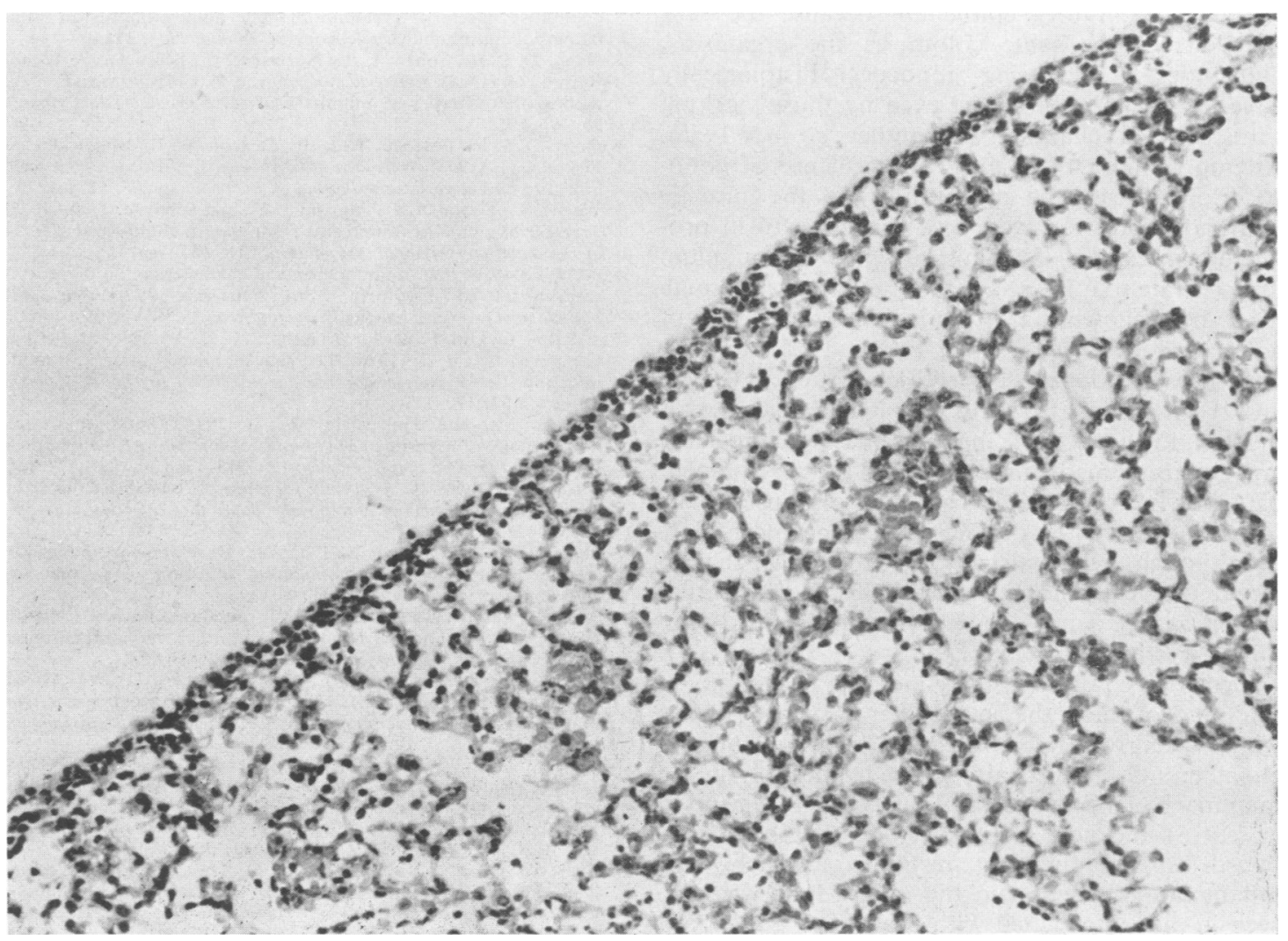

Fig. 2 Lung of CBA mouse 48 hours after intranasal inoculation of gonococci. There is alveolar wall thickening and a diffuse intra-alveolar infiltrate of mononuclear and polymorphonuclear leucocytes. These are particularly prominent at the pleural surface. $H$ and $E, \times 225$. 
isms are already trapped. This may be the reason why Turner and Novotny (1976) found that crossreactive pilar antibodies did not prevent infection from becoming established in animal chambers. However, it may be that such antibodies might prove successful in preventing infection in a situation where pilar antibodies act to prevent the attachment of gonococci to epithelial cells.

Because the chamber model is not the most appropriate for studying gonococcal infection at a mucosal surface, we attempted to establish infection in the lower respiratory tract of mice. It has been shown by others that strains of mice vary in their susceptibility to pathogenic micro-organisms (Araujo et al., 1976; Plant and Glynn, 1976). However, the three strains of mice used in this study all proved resistant to gonococcal infection. The gonococci were rarely recovered from the lungs and could not be detected histologically. Although the Gram-MGPLG stain is particularly valuable for the detection of gonococci in Fallopian tubes (Sowter and McGee, 1976), it proved less suitable for the study of respiratory epithelium because the cells stained red, the same colour as the organisms. Difficulties in detecting gonococci histologically have also been experienced even by those working with infected chambers (Chandler et al., 1976). Attempts either to enhance the virulence of gonococci or increase the susceptibility of the mice by immunosuppression were also unsuccessful in producing infection. Administration of ammonium ferric citrate to mice was without effect, even though it has been shown that iron promotes the growth of gonococci in vitro (Kellogg et al., 1968) and the virulence of gonococci for chick embryos (Payne and Finkelstein, 1975). Cyclophosphamide treatment, known to cause neutropenia (Hunninghake and Fauci, 1976), did indeed prevent the development of a polymorphonuclear leucocyte response in the lungs. However, the organisms disappeared rapidly even though they persisted for a little longer than in immunologically normal mice. This indicates that disappearance is not due solely to phagocytosis and killing by these leucocytes.

Despite the failure of the gonococci to multiply in the lungs of mice, the acute inflammatory response which occurred resembled that seen in infected chambers. Gonococci also failed to multiply in the mammary gland of the mouse (Taylor-Robinson et al., 1975) and goat (Pasieka et al., 1976) but produced an inflammatory response in each. The inflammatory reaction in the mouse lung was also seen in mice inoculated with heat-killed gonococci, suggesting that it occurred in response to the presence of a heat-stable component of the bacterial cell. As the cell walls of gonococci contain endotoxin
(Maeland, 1969), the inflammation may be mediated by activation of the alternative complement pathway. Although inoculation of the mouse lung does not provide a useful model of gonococcal infection it may be of use in studying the local effects of gonococcal endotoxin on the host.

\section{References}

Araujo, F. G., Williams, D. M., Grumet, F. C., and Remington, J. S. (1976). Strain-dependent differences in murine susceptibility to toxoplasma. Infection and Immunity, 13, 1528-1530.

Arko, R. J. (1972). Neisseria gonorrhoeae: experimental infection of laboratory animals. Science, 177, 1200-1201.

Arko, R. J. (1974). An immunologic model in laboratory animals for the study of Neisseria gonorrhoeae. Journal of Infectious Diseases, 129, $451-455$.

Brown, W. J., Lucas, C. T., and Kuhn, U. S. G. (1972). Gonorrhoea in the chimpanzee. Infection with laboratory-passed gonococci and by natural transmission. British Journal of Venereal Diseases, 48, 177-178.

Chandler, F. W., Kraus, S. J., and Watts, J. C. (1976). Pathological features of experimental gonococcal infection in mice and guinea pigs. Infection and Immunity, 13, 909-914.

Flynn, J., and Waitkins, S. A. (1973). Survival of Neisseria gonorrhoece in an artificial subcutaneous cavity of the mouse. British Journal of Venereal Diseases, 49, 432-434.

Hunninghake, G. W., and Fauci, A. S. (1976). Quantitative and qualitative effects of cyclophosphamide administration on circulating polymorphonuclear leucocytes. Immunology, 31, 139-144.

Kellogg, D. S. Jr., Cohen, I. R., Norins, L. C., Schroeter, A. L., and Reising, G. (1968). Neisseria gonorrhoeae. II. Colonial variation and pathogenicity during 35 months in vitro. Journal of Bacteriology, 96, 596-605.

Kellogg, D. S. Jr., Peacock, W. L. Jr., Deacon, W. E., Brown, L., and Pirkle, C. I. (1963). Neisseria gonorrhoeae. I. Virulence genetically linked to clonal variation. Journal of Bacteriology, 85, 1274-1279.

Lucas, C. T., Chandler, F., Martin, J. E., and Schmale, J. D. (1971). Transfer of gonococcal urethritis from man to chimpanzee. Journal of the American Medical Association, 216, 1612-1614.

Maeland, J. A. (1969). Immunochemical characterization of aqueous ether extracted endotoxin from Neisseria gonorrhoeae. Acta pathologica et microbiologica Scandinavica, 76, 484-492.

Pasieka, A. E., Ota, F., Ryan, A., Ashton, F. E., Wallace, R., Perusse, C., and Diena, B. B. (1976). The goat mammary gland as a model infection site for Neisseria gonorrhoeae. British Journal of Venereal Diseases, 52, 170-171.

Payne, S. M., and Finkelstein, R. A. (1975). Pathogenesis and immunology of experimental gonococcal infection: Rôle of iron in virulence. Infection and Immunity, 12, 1313-1318.

Plant, J., and Glynn, A. A. (1976). Genetics of resistance to infection with Salmonella typhimurium in mice. Journal of Infectious Diseases, 133, 72-78.

Scales, R. W., and Kraus, S. J. (1974). Development and passive transfer of immunity to gonococcal infection in guinea pigs. Infection and Immunity, 10, 1040-1043.

Sowter, C., and McGee, Z. A. (1976). Evaluation of a new technique for the demonstration of gonococci and other micro-organisms in host cells. Journal of Clinical Pathology, 29, 433-437.

Taylor-Robinson, D., Denny, F. W., Thompson. G. W.. Allison, A. C., and Mårdh, P.-A. (1972). Isolation of mycoplasmas from lungs by a perfusion technique. Medical Microbiology and Immuno$\log y, 158,9-15$.

Taylor-Robinson, D., Johnson, A. P., and McGee, Z. A. (1975). Use of organ cultures and small laboratory animals for the study of gonococcal infections. In Genital Infections and their Complications. First edition, pp. 243-252. Edited by D. Danielsson, L. Juhlin, and P.-A. Mårdh. Almqvist and Wiksell: Stockholm.

Turner, W. H., and Novotny, P. (1976). The inability of Neisseria gonorrhoeae pili antibodies to confer immunity in subcutaneous guinea-pig chambers. Journal of General Microbiology, 92, 224-228.

Veale, D. R., Smith, H., Witt, K. A., and Marshall, R. B. (1975). Differential ability of colonial types of Neisseria gonorrhoeae to produce infection and inflammatory response in subcutaneous perforated plastic chambers in guinea-pigs and rabbits. Journal of Medical Microbiology, 8, 325-335. 